\section{Use of Cold Water for Irrigation Reduces Stem Elongation of Plug- grown Tomato and Cabbage Seedlings}

\author{
Junne-Jih Chen, Yung-Wei Sun, and Tzay-Fa Sheen \\ Technique Department, Taiwan Seed Improvement and Propagation Station, \\ Hsinshe, Taichung, Taiwan 426, Republic of China
}

Additional index words. Lycopersicon esculentum, Brassica oleracea, stem length, temperature

\begin{abstract}
Seedlings of tomato (Lycopersicon esculentum Mill.) and cabbage (Brassica oleracea L. var. Capitata) were planted in 240-cell plug trays in the greenhouse and subjected to irrigation with water at different temperatures once a day. Irrigation with cold $\left(5\right.$ to $\left.15{ }^{\circ} \mathrm{C}\right)$ water reduced stem length of tomato by $28 \%$ to $32 \%$ in comparison with irrigation with water at room temperature $\left(27.5\right.$ to $\left.30.5^{\circ} \mathrm{C}\right)$. Use of water at $10^{\circ} \mathrm{C} \mathrm{did} \mathrm{not}$ affect total shoot dry weight but increased the shoot dry weight per centimeter of stem. Irrigation with water at $5{ }^{\circ} \mathrm{C}$ reduced stem length of cabbage seedlings $40 \%$, but use of water at 10 and $15^{\circ} \mathrm{C}$ did not. Both shoot and root dry weights were increased by irrigation with water at $10^{\circ} \mathrm{C}$. These results demonstrate that irrigation with cold water provides an effective method for improving the quality of plug-grown seedlings.
\end{abstract}

Vegetable plug seedlings are used extensively in automatic transplanting systems (Leskovar and Cantliffe, 1991; Weston and Zandstra, 1986). To facilitate handling of transplants by machines, short, sturdy seedlings of plug-grown vegetable crops are required. One major problem in commercial plug production is the control of the plant height when seedlings are grown in small plug cells, especially during the summer. Height of seedlings can be controlled by growth retardants. However, considering the legal restrictions on their use because of human health and environmental concerns, an effective nonchemical method is needed (Erwin and Heins, 1995; Moe et al., 1992).

Nonchemical strategies to control plant height include withholding water (Latimer, 1990), light quality manipulation (Liptay, 1985), shaking or brushing the shoot (Biddington and Dearman, 1985; Heuchert and Mitchell, 1983; Latimer, 1990), and temperature regulation in the greenhouse (Moe et al., 1992). In particular, emphasis has been placed on regulating day/night temperatures (Erwin and Heins, 1990; Moe et al., 1991).

The DIF concept, [difference between day (DT) and night temperature (NT)], was proposed by Erwin et al. (1989). They found that the effect of DT and NT on stem elongation could be described quantitatively using DIF. The stem elongation response to DIF has been reported in many crops, including lily (Erwin and Heins, 1995), poinsettia (Berghage and Heins, 1991), and potato (Kozai et al., 1992).

Received for publication 1 Oct. 1998. Accepted for publication 12 Feb. 1999. This work was supported by a grant from the Council of Agriculture, Republic of China. The cost of publishing this paper was defrayed in part by the payment of page charges. Under postal regulations, this paper therefore must be hereby marked advertisement solely to indicate this fact.
In general, DIF treatment of $24 \mathrm{~h}$ is applied to affect stem elongation; elongation is reduced when DT is lower than NT.

Another strategy to control growth by temperature regulation is to decrease the temperature during a specific period of the day. Moe et al. (1992) reported that a 2-h negative DIF treatment in the morning was sufficient for growth control in poinsettia. However, Ihlebekk et al. (1995) reported that a minimum of $9 \mathrm{~h}$ of low temperature during the photoperiod is usually required for the control of seedling growth in Campanula isophylla. Compared to the 24-h DIF treatment, a short lowtemperature treatment saves more energy, but it is hard to put into practice in commercial plug production systems. This study was designed during the first few weeks after seeding and before transplanting could influence the growth and quality of tomato and cabbage seedlings.

\section{Materials and Methods}

The experiment was conducted at the Taiwan Seed Improvement and Propagation Station in 1997. Two vegetable crops with different stem elongation types, tomato (cv. YASU No. 5 ) and cabbage (cv. K-Y cross), were used. Seeds were sown, three per cell, in 240cell plug trays $\left(60 \times 40 \times 4.8 \mathrm{~cm}, 18.9 \mathrm{~cm}^{3}\right.$ per cell; Visser Co., The Netherlands) containing a peat/sea-sand medium (BVB No. 4; Bas Van Buuren Co., The Netherlands). After $95 \%$ of the seeds germinated, the seedlings were manually thinned to one per cell. Each plug tray was fertigated with $1.5 \mathrm{~L}$ of liquid fertilizer containing $400 \mathrm{mg} \cdot \mathrm{L}^{-1} \mathrm{~N}$ (Peter's 20N-20P-20K; Scotts-Sierra Horticultural Products Co., Maryville, Ohio) by overhead sprinkler once a week. The plug trays were kept on adjacent benches in a plastic-covered greenhouse $(90 \%$ of light penetration) throughout the experito examine whether irrigation with cold water ment. Temperature and light intensity were recorded with a data-logger (CD750; Priva Co., De Lier, The Netherlands). One tray was assigned to each irrigation treatment in a randomized complete-block design with three replications. Treatments were initiated 5 to $7 \mathrm{~d}$ after seeding, when the first true leaf was beginning to expand. Cold-water $(5,10$, or 15 ${ }^{\circ} \mathrm{C}$ ) irrigation treatments were supplied from temperature-controlled tanks. The control (water at room temperature) used water pumped directly from a tank built in the greenhouse. Irrigation water was applied once a day at $0900 \mathrm{HR}$. No additional irrigation was applied during the day. The seedlings were watered by overhead sprinkler until water dripped from the bottom of the plug tray. About 5 to $6 \mathrm{~mL}$ of water was retained in each cell after each irrigation.

The average temperature during the experiment was $28.5^{\circ} \mathrm{C}$ and average maximum light intensity was $2025 \mu \mathrm{mol} \cdot \mathrm{m}^{-2} \cdot \mathrm{s}^{-1}$ photosynthetic photon flux $(P P F)$. At the time coldwater treatment started $(0900 \mathrm{HR})$, air temperature ranged from 27.5 to $30.5{ }^{\circ} \mathrm{C}$ and light intensity from 1215 to $1485 \mu \mathrm{mol} \cdot \mathrm{m}^{-2} \cdot \mathrm{s}^{-1} P P F$. The temperature of the growing medium dropped 6 to $9{ }^{\circ} \mathrm{C}$ within 3 min of irrigation with cold water, then rose to the original temperature after 1.5 to $2 \mathrm{~h}$.

Fifteen seedlings per block were sampled randomly from each treatment, and stem length and diameter were determined immediately. Stem length was measured from the base of the stem to the top of the shoot. Chlorophyll (Chl) was extracted in absolute methanol and analyzed spectrophotometrically (Holder, 1965). For shoot and root dry-weight determination, samples were dried at $80^{\circ} \mathrm{C}$ for $2 \mathrm{~d}$.

The statistical significance of treatment differences was evaluated by the least significant differences (LSD) test.

\section{Results}

Stem length of tomato seedlings was significantly reduced by irrigation with cold water within $24 \mathrm{~d}$ of culturing (Fig. 1A). Thereafter, stem length increased steadily but at a slower rate as compared with the control seedlings. Differences among cold-water treatments were nonsignificant. The average stem lengths at $35 \mathrm{~d}$ were 19.8 and $13.7 \mathrm{~cm}$ for the control and the cold water-treated seedlings, respectively. For the cabbage seedlings, irrigation with water at $5{ }^{\circ} \mathrm{C}$ significantly inhibited stem growth. However, water at 10 and 15 ${ }^{\circ} \mathrm{C}$ did not (Fig. 1B).

To examine whether the growth characteristics other than stem length were affected by cold-water treatment, tomato and cabbage seedlings were irrigated with water at $10^{\circ} \mathrm{C}$ or at room temperature. The $10^{\circ} \mathrm{C}$ water treatment had no effect on tomato shoot dry weight as of day 35 , but reduced root dry weight $8.6 \%$ (Table 1). In contrast, the same treatment significantly increased both shoot and root dry weight of cabbage. At day 35 of culture, shoot and root dry weights were $16.5 \%$ and $13.3 \%$ greater, respectively, than those of control seedlings (Table 1). 


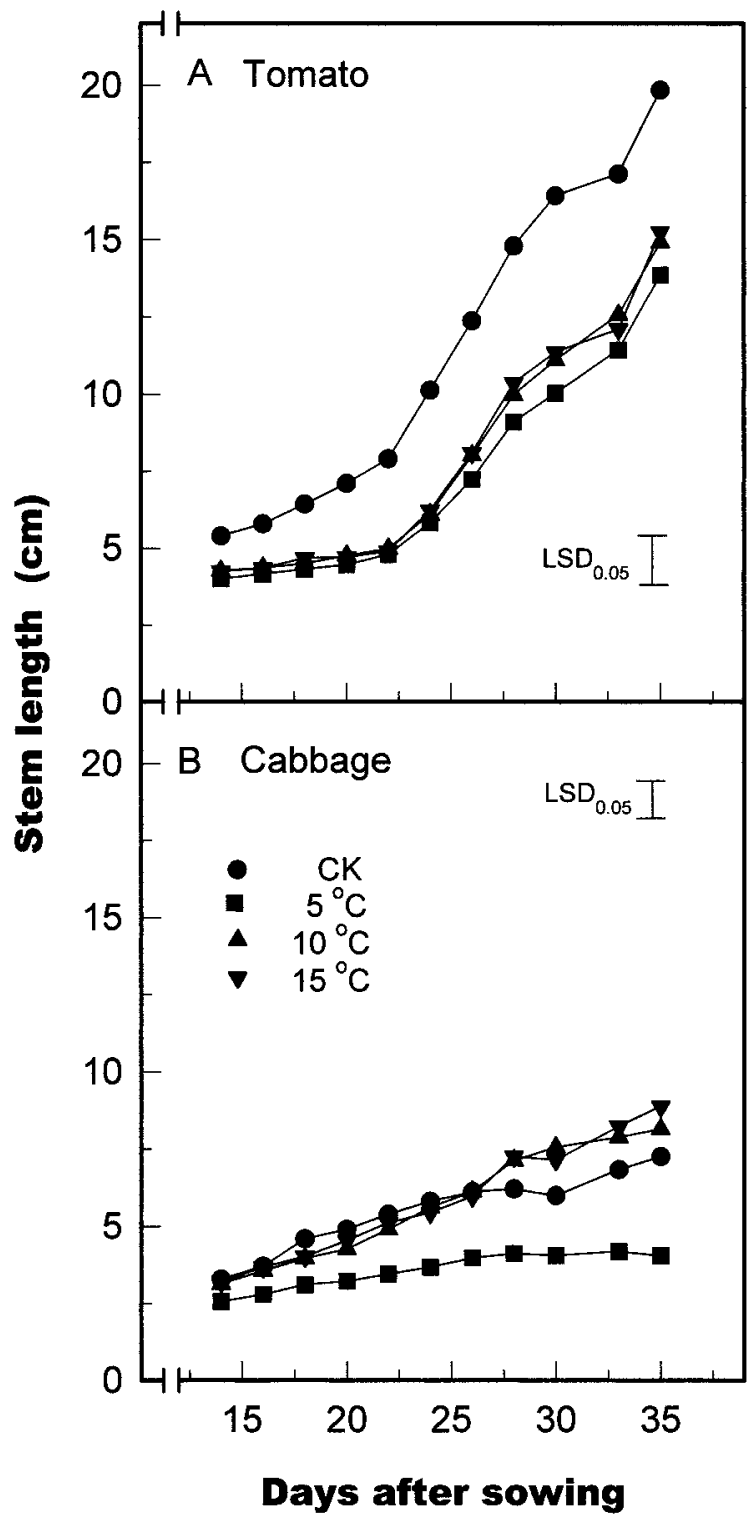

Fig. 1. Effect of temperature of irrigation water on stem length of (A) tomato and (B) cabbage seedlings. Each point is the mean for 15 seedlings. Least significant difference values are based on the pooled variance of all treatments.

Table 1. Effects of temperature of irrigation water on the growth characters of greenhouse-grown tomato and cabbage seedlings. ${ }^{\mathrm{T}}$

\begin{tabular}{|c|c|c|c|c|c|c|}
\hline $\begin{array}{l}\text { Water } \\
\text { temperature }\end{array}$ & $\begin{array}{l}\text { Stem } \\
\text { length } \\
(\mathrm{cm})\end{array}$ & $\begin{array}{l}\text { Shoot DW } \\
\text { (mg/plant) }\end{array}$ & $\begin{array}{c}\text { Root DW } \\
\text { (mg/plant) }\end{array}$ & $\begin{array}{l}\text { Shoot DW } \\
\text { per } \mathrm{cm} \mathrm{of} \mathrm{ht}^{\mathrm{y}} \\
\left(\mathrm{mg} \cdot \mathrm{cm}^{-1}\right)\end{array}$ & $\begin{array}{l}\text { Stem } \\
\text { diam } \\
(\mathrm{mm})\end{array}$ & $\begin{array}{c}\text { Leaf } \\
\text { chlorophyll } \\
\text { content } \\
\left(\mu \mathrm{g} \cdot \mathrm{cm}^{-2}\right) \\
\end{array}$ \\
\hline \multicolumn{7}{|c|}{ Tomato } \\
\hline $10{ }^{\circ} \mathrm{C}$ & 14.2 & 238 & 21.2 & 16.0 & 2.38 & 6.72 \\
\hline Control $^{x}$ & 19.8 & 255 & 24.4 & 13.4 & 2.89 & 6.71 \\
\hline $\mathrm{LSD}_{0.05}$ & 2.3 & NS & 2.6 & 2.3 & 0.34 & NS \\
\hline \multicolumn{7}{|c|}{ Cabbage } \\
\hline $10^{\circ} \mathrm{C}$ & 8.1 & 200 & 18.4 & 25.9 & 2.62 & 8.40 \\
\hline Control & 7.2 & 176 & 15.8 & 25.3 & 2.73 & 8.17 \\
\hline $\mathrm{LSD}_{0.05}$ & NS & 14 & 2.8 & NS & NS & NS \\
\hline
\end{tabular}

${ }^{2}$ Mean of 15 samples.

yDW = dry weight; ht $=$ height.

${ }^{x}$ Water temperature at the time of irrigation $(0900 \mathrm{HR})$ ranged from 27.5 to $30.5^{\circ} \mathrm{C}$.

Ns Nonsignificant at $P \leq 0.05$.
The $10{ }^{\circ} \mathrm{C}$ water treatment increased tomato shoot dry weight to stem length ratio, a quality characteristic of tomato. However, no such difference was observed in cabbage. Stem diameter was reduced in tomato but not in cabbage. Leaf chlorophyll content was not affected in either species (Table 1).

\section{Discussion}

One of the major problems in commercial tomato seedling production is the control of plant height. In this study, irrigation with cold water reduced stem length $28 \%$ (Table 1). The stem elongation pattern can be characterized by internode number and internode length, which vary with temperature (Berghage and Heins, 1991). In our study, internode numbers were not affected in tomato (five internodes, data not shown); reduction of seedling height by cold-water treatment was a result of a decrease in internode length. Water at temperatures from 5 to $15^{\circ} \mathrm{C}$ had a similar effect. Seedlings were shorter and sturdier than control seedlings (Table 1).

In contrast with tomato, cabbage is a shortstem type crop. This may explain why the cold-water treatment did not reduce stem length. However, shoot and root dry weights were both increased, which should result in improved suitability for transplanting (Biddington and Dearman, 1985).

Mechanical stress generally affects shoot and/or root dry weight and the partitioning of dry weight (Biddington, 1986; Latimer, 1990; Watts et al., 1981). Latimer (1990) found that the ratio of shoot-to-root dry weight of broccoli (Brassica oleracea L. Group Italica) transplants increased during drought. In lily (Lilium longflorum Thunb.), the stem dry weight increased linearly as DIF increased and the percentage of partitioning of dry weight into stem depended primarily on day temperature (Erwin and Heins, 1995; Erwin et al., 1989). In this study, we found that the cold-water treatment did not affect the ratio of shoot-to-root dry weight significantly for either tomato or cabbage.

Nitrogen is a major factor affecting vegetable seedling growth (Dufault, 1986, 1998). Melton and Dufault (1991) reported that nitrogen accounted for the major portion of variations in height and leaf chlorophyll content of tomato transplants. Generally, shoot and root growth decreased as $\mathrm{N}$ rate decreased (Weston and Zandstra, 1989). Many researchers have suggested that the retardation of seedling growth by chilling stress is related to inadequate nutrient uptake, presumably due to root damage (Bolger et al., 1992; Reyes and Jennings, 1994). However, this was not the case in the present study. Even with the large temperature drop induced by irrigation with water at $5{ }^{\circ} \mathrm{C}$, the temperature in the growing medium remained no lower than 18 to $20^{\circ} \mathrm{C}$ level. These temperatures should not inhibit growth (Reyes and Jennings, 1994). Also, total plant dry weight and leaf chlorophyll content were either not affected or increased in response to cold-water treatment. This indicates that the effects of cold-water treatments 
used on plant height were mediated by a different mechanism in this study, probably by inducing endogenous ethylene production (Biddington, 1986; Lanahan et al., 1994).

The influence of temperature on stem elongation has been studied with an emphasis on the effects of DIF treatment (Erwin and Heins, 1991, 1995). Such treatments require environmental control, and in addition, the degree of response varies with plant species, stage of plant development and the temperature difference (Berghage and Heins, 1991; Erwin and Heins, 1995; Moe et al., 1992). The DIF treatment is usually applied by ventilating the greenhouse with cool outside air at sunrise for 1 or $2 \mathrm{~h}$ and is used extensively in U.S. commercial plug production (Moe et al., 1992). In this study, we tested a simple method for controlling seedling growth that could also be used commercially. Tomato seedling height especially was reduced by irrigating with cold water. To our knowledge, this is the first report on controlling the height of greenhouse-grown containerized seedlings using a cold-water irrigation treatment.

\section{Literature Cited}

Berghage, R.D. and R.D. Heins. 1991. Quantification of temperature effects on stem elongation in poinsettia. J. Amer. Soc. Hort. Sci. 116:14-18.

Biddington, N.L. 1986. The effects of mechanicalinduced stress in plants- A review. Plant Growth Regulat. 4:103-123.

Biddington, N.L. and A.S. Dearman. 1985. The effect of mechanically induced stress on the growth of cauliflower, lettuce and celery seedlings. Ann. Bot. 55:109-119.

Bolger, T.P., D.R. Upchurch, and B.L. McMichael. 1992. Temperature effects on cotton root conductance. Environ. Expt. Bot. 32:49-54.

Dufault, R.J. 1986. Influence of nutritional conditioning on muskmelon transplant quality and early yield. J. Amer. Soc. Hort. Sci. 11:698-703.

Dufault, R.J. 1998. Vegetable transplant nutrition. HortTechnology 8:515-523.

Erwin, J.E. and R.D. Heins. 1990. Temperature effects on lily development rate and morphology from the visible bud stage until anthesis. J. Amer. Soc. Hort. Sci. 115:644-646.

Erwin, J.E. and R.D. Heins. 1991. Diurnal variation in temperature affects carbon partitioning in New Guinea impatiens and fuchsia shoots. HortScience 26:117.

Erwin, J.E. and R.D. Heins. 1995. Thermomorphogenic responses in stem and leaf development. HortScience 30:940-949.

Erwin, J.E., R.D. Heins, and M.G. Karlsson. 1989. Thermomorphogenesis in Lilium longflorum Thunb. Amer. J. Bot. 76:47-52.

Heuchert, J.C. and C.A. Mitchell. 1983. Inhibition of shoot growth in greenhouse grown tomato by periodic gyrator shaking. J. Amer. Soc. Hort. Sci. 108:795-800.

Holder, M. 1965. Chlorophyll, p. 461-488. In: T.W. Goodwin (ed.). Plant pigments. Academic Press, New York.

Ihlebekk, H., S. Eilertsen, O. Junttila, G. Grindal, and R. Moe. 1995. Control of plant height in Campanula isophylla by temperature alternations; involvement of GAs. Acta Hort. 394:347355.

Kozai, T., S. Kushihashi, C. Kubota, and K. Fujiwara. 1992. Effect of the difference between photoperiod and dark period temperature, and photosyn- thetic photon flux density on the shoot length and growth of potato plantlets in vitro (in Japanese). J. Jpn. Soc. Hort. Sci. 61:93-98.

Lanahan, M.B., H.C. Yen, J.J. Glovannoni, and M.J. Klee. 1994. The never ripe mutation blocks ethylene perception. Plant Cell 6:521-530.

Latimer, J.G. 1990. Drought or mechanical stress affects broccoli transplant growth and establishment but not yield. HortScience 25:1223-1235.

Leskovar, D.I. and D.J. Cantliffe. 1991. Tomato transplant morphology affected by handling and storage. HortScience 26:1377-1379.

Liptay, A. 1985. Reduction of spindliness of tomato transplants grown at high densities. Can J. Plant Sci. 65:797-801.

Melton, R.R. and R.J. Dufault. 1991. Nitrogen, phosphorus, and potassium fertility regimes affect tomato transplant growth. HortScience 26:141-142.

Moe, R., N. Glomsrud, I. Bratberg, and S. Valso. 1992. Control of height in poinsettia by temperature drop and graphical tracking. Acta Hort. 327:41-48.

Reyes, E. and P.H. Jennings. 1994. Response of cucumber (Cucumis sativus L.) and squash (Cucurbita pepo L. var. melopepo) roots to chilling stress during early stages of seedling development. J. Amer. Soc. Hort. Sci. 119:964970 .

Watts, S., J.L. Rodriguez, S.E. Evans, and W.J. Davies. 1981. Root and shoot growth of plants treated with abscisic acid. Ann. Bot. 47:595-602.

Weston, L.A. and B.H. Zandstra. 1986. Effect of root container size and location of production on growth and yield of tomato transplants. J. Amer. Soc. Hort. Sci. 11:498-501.

Weston, L.A. and B.H. Zandstra. 1989. Transplant age and $\mathrm{N}$ and $\mathrm{P}$ nutrition effects on growth and yield of tomatoes. HortScience 24:88-90. 